\title{
In vitro functional comparison of therapeutically relevant human vasculogenic progenitor cells used for cardiac cell therapy
}

\author{
Yan Zhang, MD, MSc, ${ }^{\mathrm{a}, \mathrm{b}, *}$ Serena Wong, BSc, ${ }^{\mathrm{a}, \mathrm{b}, *}$ Jessica Laflèche, BSc, ${ }^{\mathrm{a}, \mathrm{b}}$ Suzanne Crowe, ${ }^{\mathrm{a}}$ \\ Thierry G. Mesana, MD, PhD, ${ }^{a}$ Erik J. Suuronen, PhD, ${ }^{\mathrm{a}, \mathrm{b}}$ and Marc Ruel, MD, MPH ${ }^{\mathrm{a}, \mathrm{b}}$
}

\begin{abstract}
Objective: In cardiac cell therapy almost every cell type tested experimentally has yielded some benefit. However, there is a lack of studies directly comparing the function of various stem/progenitor cell populations. This study describes the expansion of peripheral blood $\mathrm{CD}_{133^{+}}$cells and compares their functional properties with those of other commonly used human progenitor cell populations.
\end{abstract}

\begin{abstract}
Methods: $\mathrm{CD} 133^{+}$cells were generated from the $\mathrm{CD} 133^{-}$fraction of peripheral blood, either serially (pooledderived) or after 14 days of culture (derived). Their phenotypic, migratory, and vasculogenic properties were compared with those of 4 commonly used progenitor cell populations in vitro.
\end{abstract}

Results: Serial expansion resulted in an 11-fold increase in the number of CD133 ${ }^{+}$cells. The proportion of derived $\mathrm{CD} 133^{+}$cells collected between 0 and 8 days also expressing CD34 and vascular endothelial growth factor receptor 2 was similar (approximately $60 \%, P=.41$ ). Adherent, 4-day cultured endothelial progenitor cells demonstrated enhanced migration compared with each of the other 5 cell populations (all $P \leq .002$ ). The migration of derived $\mathrm{CD} 133^{+}$progenitors was enhanced by coculture with $\mathrm{CD} 133^{-}$cells or their supernatant $(P<.05)$. In vitro vasculogenesis assays revealed that derived and pooled-derived $\mathrm{CD} 133^{+}$cells had superior vasculogenic potential compared with other progenitor populations $(P \leq .03)$.

Conclusions: A novel source of expandable CD133 ${ }^{+}$cells can be generated from the CD133- fraction of peripheral blood. The CD133 phenotypic marker translates into the cell being vasculogenically more potent in vitro, which could be beneficial to inducing vasculogenesis in the ischemic heart. Furthermore, intercellular interactions appear important for improving the therapeutic efficacy of cell transplantation. (J Thorac Cardiovasc Surg 2010;140:216-24)

Supplemental material is available online.

Cardiac cell-based therapies, one of the major areas of translational research in which cardiac surgeons play a key role, involve the delivery of stem/progenitor cells to areas of the ischemic tissue and infarcted myocardium to stimulate and accelerate the processes of vasculogenesis, myogenesis, or both. ${ }^{1}$ A number of different cell types have been trans-

From the Division of Cardiac Surgery, ${ }^{\mathrm{a}}$ University of Ottawa Heart Institute, and the Department of Cellular and Molecular Medicine, ${ }^{\mathrm{b}}$ University of Ottawa, Ottawa, Ontario, Canada.

Supported by the Canadian Institutes of Health Research (to Drs Ruel and Suuronen, grant MOP-77536), by the Canadian Foundation for Innovation (to Dr Ruel, award 7346), and by the Heart and Stroke Foundation of Canada Doctoral Research Award (to Dr Zhang).

Disclosures: None.

* Y. Zhang and S. Wong contributed equally to this work.

Received for publication June 30, 2009; revisions received Oct 15, 2009; accepted for publication Nov 3, 2009; available ahead of print Feb 18, 2010.

Address for reprints: Marc Ruel, MD, MPH, and Erik J. Suuronen, Division of Cardiac Surgery, University of Ottawa Heart Institute, 40 Ruskin St, Ottawa, Ontario, K1Y 4W7, Canada (E-mail: mruel@ottawaheart.ca; esuuronen@ottawaheart.ca).

$0022-5223 / \$ 36.00$

Copyright (c) 2010 by The American Association for Thoracic Surgery doi:10.1016/j.jtcvs.2009.11.016 planted into the hearts of experimental animals or patients with coronary artery disease (CAD), and almost every cell type tested has yielded some degree of benefit experimentally. However, clinical benefits have been modest. Today, there remain major hurdles in cell expansion, delivery, adhesion, local amplification, vascularization, and functional incorporation (Figure 1).

One issue that needs to be addressed is the identification of the "ideal" stem/progenitor cell population for optimal vasculogenesis considering how important the paracrine/humoral mechanism might be. ${ }^{2}$ In clinical use autologous cells from the blood, bone marrow (BM), or other tissues are favored because they circumvent the potential problems associated with ethics, availability, and immune responses. Several heterogeneous and preselected progenitor cell populations derived from $\mathrm{BM}$ or peripheral blood $(\mathrm{PB})$ mononuclear cells (MNCs), such as mesenchymal stem cells (MSCs), endothelial progenitor cells (EPCs), or circulating progenitor cells, have been used in various experimental and clinical settings. ${ }^{3-6}$ One cell population of interest for therapeutic vasculogenesis in the ischemic or infarcted myocardium is the MSC. Transplanting MSCs into the heart has been shown to improve its perfusion and function. ${ }^{3}$ Another cell population, the circulating progenitor cells, which include EPCs, can home to injured tissues and are important 


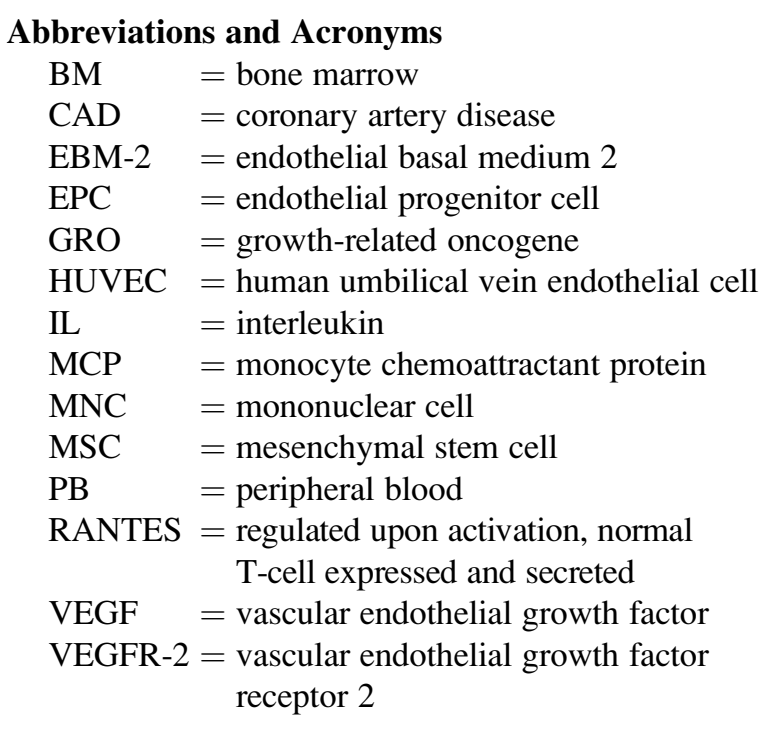

for vascular repair and maintenance. ${ }^{3,6} \mathrm{~A}$ variety of cell sources, isolation methods, and culture conditions have been used to produce mainly heterogeneous populations of EPCs for transplantation. One commonly used ex vivo expansion technique yields 4- to 7-day adherent EPCs from the culture of circulating PB-MNCs on fibronectin. ${ }^{6}$

Preselection to obtain more specific subpopulations of EPCs can be performed, involving an isolation of cells based on markers, such as CD34, vascular endothelial growth factor receptor 2 (VEGFR-2), and/or CD133. ${ }^{7}$ CD34 and VEGFR-2 are both expressed at lower levels on mature endothelial cells, whereas CD133, also known as prominin or $\mathrm{AC} 133$, is expressed on hematopoietic stem cells but is absent on mature endothelial cells and monocytic cells. Although CD133 might be a more specific marker of stem/ progenitor cells and might provide a clinical benefit, ${ }^{8}$ its functional role in cell biology remains uncertain.

Recently, the PB became a preferred cell source for regenerative therapy considering its noninvasiveness and easy availability. However, the frequency of $\mathrm{CD} 133^{+} \mathrm{CD} 34^{+}$VEGFR-2 $2^{+}$ cells in total PB-MNCs is very low (approximately $0.002 \%$ ). ${ }^{9}$ Although some research showed that granulocyte colonystimulating factor-mobilized blood from patients contains 5- to 100-fold higher levels of MSCs and EPCs compared with nonmobilized blood, ${ }^{10}$ the ability of these cells to improve cardiac remodeling and function after acute myocardial infarction (AMI) has been disappointing. ${ }^{11}$

Consequently, one first step for clinical stem cell therapy would be to obtain large amounts of homogenous and wellcharacterized cells and study them. In this regard we identified a new subpopulation of EPCs, termed "derived" $\mathrm{CD}_{133^{+}} \mathrm{PB}$ cells. ${ }^{12}$ These cells demonstrated improved adhesion and ability to form capillary-like structures in vitro compared with freshly isolated $\mathrm{CD} 133^{+}$progenitors from the $\mathrm{PB}$.

Many studies have examined the efficacy of different progenitor cell populations individually; however, direct functional studies that compare several cell populations are lacking. Additionally, intercellular interactions can have a significant effect on the functional activity of progenitor populations both in vitro and in vivo, ${ }^{3,12}$ and further elucidation of these interactions and cytokine influence might benefit the optimization of cell therapy strategies. Therefore assessing the vasculogenic properties and interactions of different EPC and BM populations might be invaluable to optimize clinical cell-based therapeutic vasculogenesis. This study was designed to (1) investigate methods of $\mathrm{CD} 133^{+}$

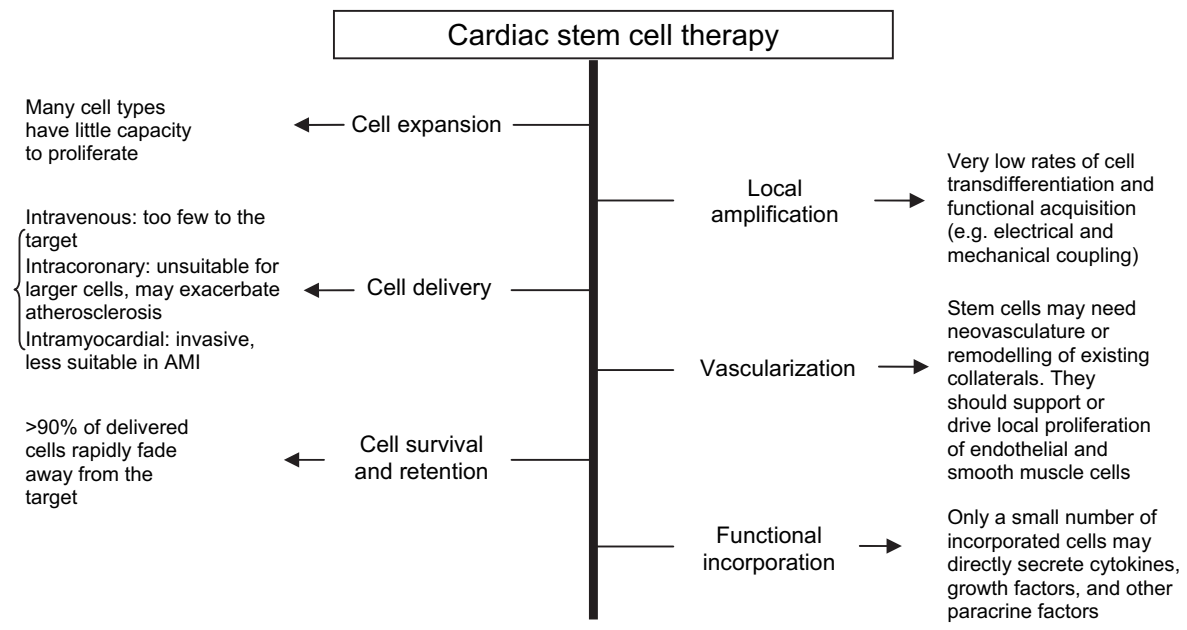

FIGURE 1. Hurdles in cardiac cell therapy. AMI, Acute myocardial infarction. 
TABLE 1. Patients' characteristics

\begin{tabular}{lcccc}
\hline & All patients $(\mathbf{n = 1 2})$ & $\begin{array}{c}\text { Aortic valve } \\
\text { disease }(\mathbf{n}=\mathbf{6})\end{array}$ & $\begin{array}{c}\text { Mitral valve disease } \\
(\mathbf{n}=\mathbf{5})\end{array}$ & $\begin{array}{c}\text { Aortic and mitral valve } \\
\text { disease }(\mathbf{n}=\mathbf{1})\end{array}$ \\
\hline Age (y) & $64.7 \pm 10.7$ & $65.7 \pm 8.3$ & $61.0 \pm 13.0$ & 79 \\
Male/female sex (n) & $10 / 2$ & $5 / 1$ & $5 / 0$ & $0 / 1$ \\
CAD (n) & 0 & 0 & 0 & 0 \\
Diabetes (n) & 0 & 0 & 0 & 0 \\
CHF (n) & $2(17 \%)$ & 1 & 1 & 0 \\
Hypertension (n) & $5(42 \%)$ & 3 & 1 & 1 \\
Hypercholesterolemia (n) & $5(42 \%)$ & 2 & 2 & 1 \\
Smoking (n) & $4(33 \%)$ & 2 & 2 & 0 \\
\hline
\end{tabular}

$C A D$, Coronary artery disease; $C H F$, congestive heart failure.

$\mathrm{PB}$ cell expansion, (2) characterize derived $\mathrm{CD} 133^{+} \mathrm{PB}$ cells and the influence of intercellular interactions on their function, and (3) evaluate their vasculogenic and migratory properties in comparison with other commonly used human progenitor populations from the $\mathrm{PB}$ and $\mathrm{BM}$.

\section{MATERIALS AND METHODS}

\section{Cell Isolation and Expansion}

This study was approved by the Human Research Ethics Board of the University of Ottawa Heart Institute. After acquiring informed consent from human patient donors undergoing valve surgery $(n=12)$ without concomitant $\mathrm{CAD}$ or diabetes (to limit interpatient variability in progenitor cell function), both PB and sternal BM were harvested immediately after sternotomy. Details of patients' characteristics are found in Table 1.

Overall, 6 different populations of stem/progenitor cells were obtained from $\mathrm{PB}$ or BM, as described in the online supplemental Materials and Methods section: (1) fresh $\mathrm{CD} 133^{+} \mathrm{PB}$ cells, (2) derived $\mathrm{CD} 133^{+} \mathrm{PB}$ cells, (3) pooled-derived CD133 ${ }^{+} \mathrm{PB}$ cells, (4) "classical" EPCs, (5) fresh CD133+ BM cells, and (6) MSCs. Cell counts and viability were determined by using a cell counter (Beckman Coulter, Mississauga, Ontario, Canada).

Briefly, to obtain derived CD $133^{+} \mathrm{PB}$ cells from $\mathrm{CD} 133^{-}$fractions, 2 different protocols were used. Cells in protocol 1 had fresh media added every 3 days without aspiration of the old media. After 14 days, both adherent and nonadherent cells were collected and separated to obtain derived CD133 ${ }^{+}$ $\mathrm{PB}$ cells. In protocol 2 the nonadherent population was removed every 2 days over a period of 8 days, separated to collect the $\mathrm{CD} 133^{+}$cells, and cryopreserved. After 8 days, cryopreserved cells were combined to constitute the pooled-derived $\mathrm{CD} 133^{+}$population. Cell phenotype was analyzed by using flow cytometry (FACSAria cell sorting system; BD Biosciences, San Jose, Calif). Details are provided in the online supplemental Materials and Methods section.

\section{Investigation of $\mathrm{CD}^{2} 3^{+}$Cell Generation}

Freshly isolated CD133- $\mathrm{PB}$ cells were cultured to determine possible inhibitory mechanisms on the generation of $\mathrm{CD} 133^{+}$cells under the following conditions: (1) supernatant from whole PB-MNCs, (2) fresh CD133 ${ }^{+} \mathrm{PB}$ cells, and (3) supplemented endothelial basal medium 2 (EBM-2 [control]; Clonetics, Guelph, Canada). After 48 hours of exposure, the adherent and nonadherent cells from each condition were lifted and separated to obtain the $\mathrm{CD} 133^{+}$cells, and the numbers of derived $\mathrm{CD} 133^{+}$cells were determined.

\section{In Vitro Migration Assay}

Each of the 6 cell populations were labeled with CellTracker Orange (Molecular Probes, Eugene, Ore), and then $2 \times 10^{4}$ labeled cells of each type were placed separately in the upper chamber with EBM-2 without VEGF. ${ }^{13}$ The lower chamber contained serum-free media with $50 \mathrm{ng} / \mathrm{mL}$ vascular endothelial growth factor (VEGF; Sigma, Oakville, Canada). After 24 hours of incubation, cells migrated into the lower chamber were counted manually from 6 random high-powered fields.
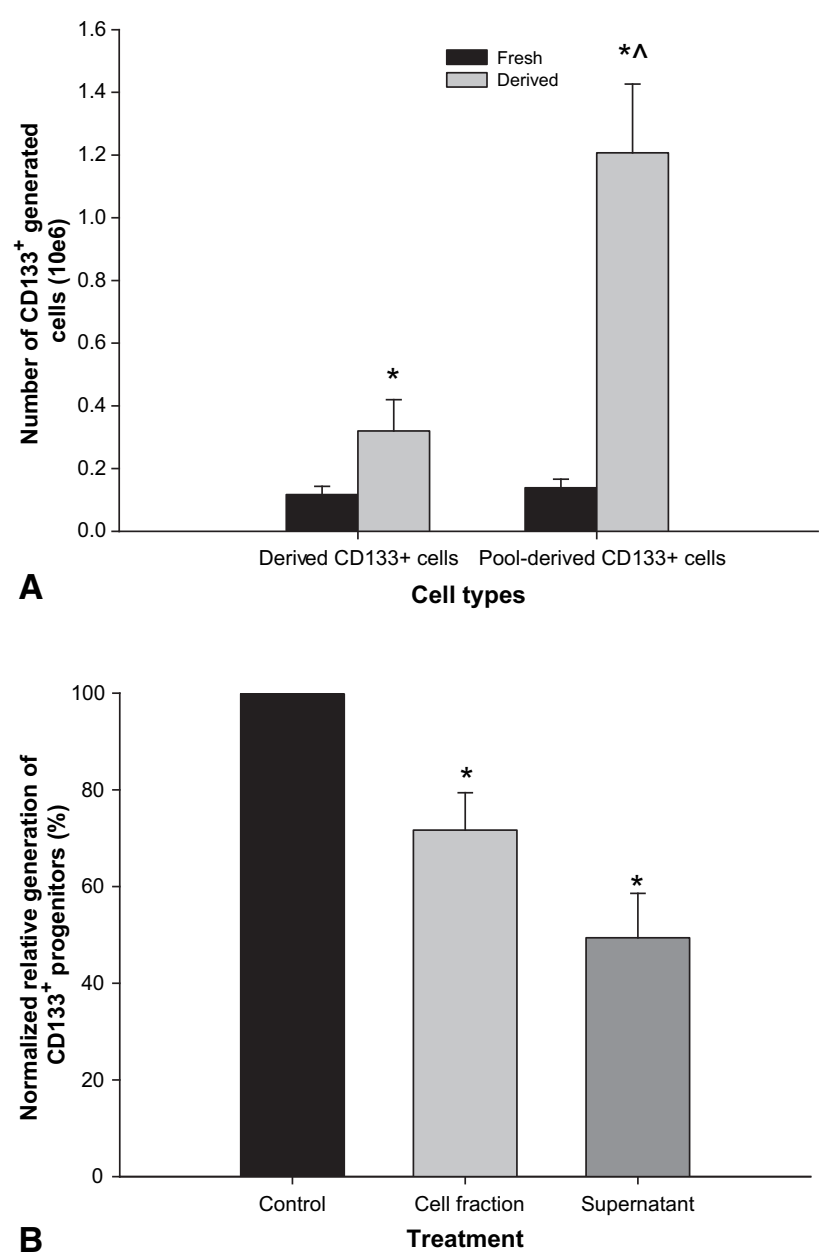

FIGURE 2. A, The number of pooled-derived CD $133^{+}$cells (derived serially) was significantly greater than that of derived $\mathrm{CD} 133^{+}$cells (after 14 days of culture). $* P<.05$ versus fresh $\mathrm{CD} 133^{+}$cells; ${ }^{\wedge} P<.05$ versus derived $\mathrm{CD} 133^{+}$cells. $\mathrm{B}$, The presence of a peripheral blood mononuclear cell $(P B-M N C)$ supernatant or $\mathrm{CD} 133^{+}$cells (from whole PB-MNCs) inhibited the generation of $\mathrm{CD} 133^{+}$cells from the $\mathrm{CD} 133^{-}$fraction compared with normal expansion conditions (Control). $* P<.003$ versus control. 

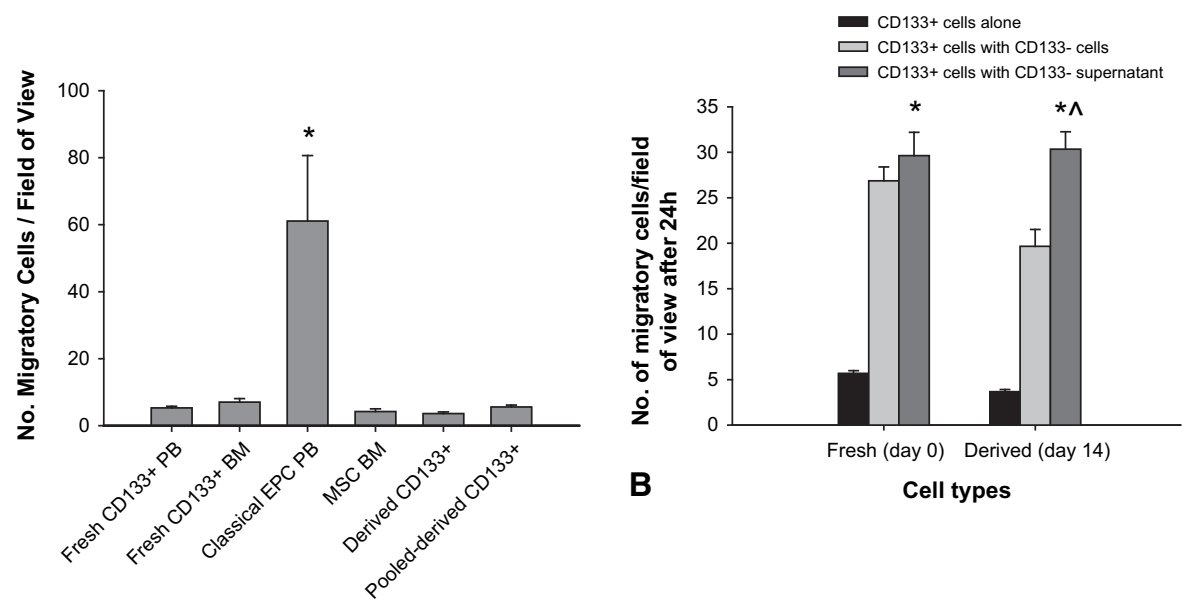

A

Progenitor Cell Populations

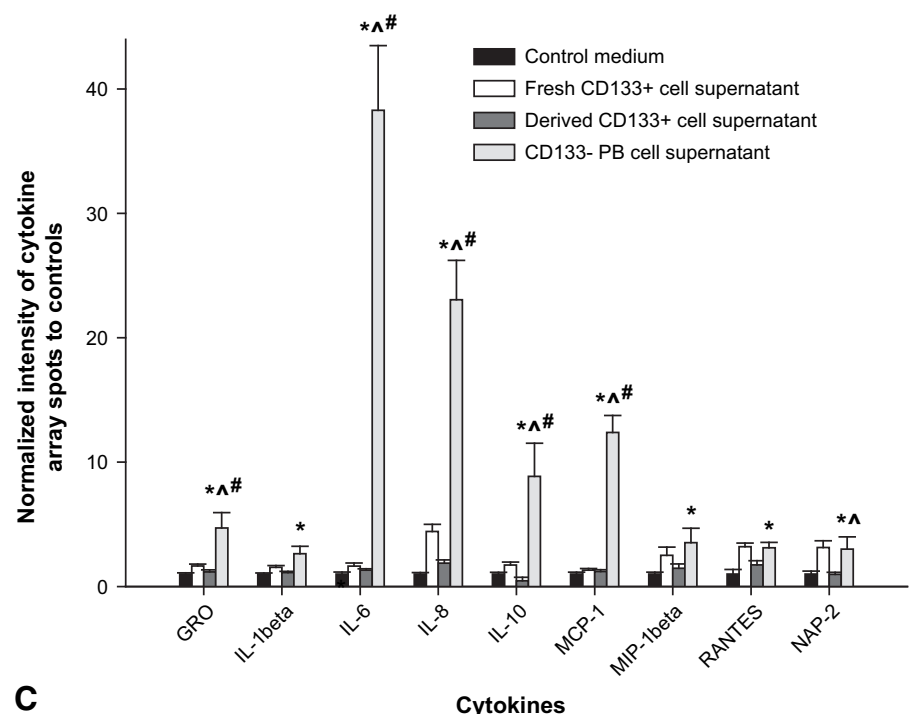

FIGURE 3. A, The average number per field of view of migrating cells for the 6 progenitor populations. $* P<.001$ versus all other cell populations. $P B$, Peripheral blood; $B M$, bone marrow; $E P C$, endothelial progenitor cell; $M S C$, mesenchymal stem cell. B, The number per high-powered field of migrating $\mathrm{CD} 133^{+}$cells (fresh or derived) with CD133- cells or its supernatant after 24 hours of culture. $* P \leq .005$ versus CD133 ${ }^{+}$cells alone; $\wedge P<.05$ versus incubation with $\mathrm{CD} 133^{-}$cells. C, Relative expression of selected cytokines and growth factors (normalized to control values for each cytokine). ${ }^{*} P<.005$ versus control media; $\wedge P<.05$ versus supernatant of fresh $\mathrm{CD} 133^{+}$peripheral blood cells; $\# P<.05$ versus supernatant of derived $\mathrm{CD} 133^{+}$peripheral blood cells. GRO, Growth-related oncogene; $I L$, interleukin; $M C P-1$, monocyte chemoattractant protein 1; MIP-1beta, macrophage inflammatory protein $1 \beta$; RANTES, regulated upon activation normal $\mathrm{T}$ cell expressed and secreted; NAP-2, neutrophil-activating protein 2.

\section{Interactions Between $\mathrm{CD}^{+33^{+}}$and $\mathrm{CD}^{-} 3^{-} \mathrm{PB}$ Fractions}

The cell groups were as follows: (1) fresh $\mathrm{CD} 133^{+} \mathrm{PB},(2)$ derived $\mathrm{CD} 133^{+} \mathrm{PB}$, (3) fresh CD133 ${ }^{+} \mathrm{PB}$ combined with fresh CD133- $\mathrm{PB}$, (4) derived $\mathrm{CD} 133^{+} \mathrm{PB}$ combined with fresh $\mathrm{CD} 133^{-} \mathrm{PB}$, (5) fresh $\mathrm{CD} 133^{+} \mathrm{PB}$ with the $\mathrm{CD}_{133^{-}}$supernatant, and (6) derived $\mathrm{CD} 133^{+} \mathrm{PB}$ with the $\mathrm{CD} 133^{-}$supernatant. Cell migratory potential was assessed according to the methods described previously. ${ }^{12}$ Before and after culture, flow cytometric analysis was performed to determine the expression of VEGFR-2 on $\mathrm{CD}_{133^{+}}$cells in the first 4 groups.

\section{Cytokine Antibody Array}

We sought to determine the cytokines present in the supernatants of various cell populations after 24 hours of culture with the human cytokine antibody array V (RayBiotech, Norcross, Ga). The cell populations examined were as follows: (1) fresh $\mathrm{CD} 133^{+} \mathrm{PB},(2)$ derived $\mathrm{CD} 133^{+} \mathrm{PB}$, and (3) fresh CD133- PB. Supplemented EBM-2 was used as a control, and the differences in the level of each growth factor and cytokine were quantified against internal controls within the array and then compared between cell populations as fold changes. Kodak 1D Imaging software (Kodak, Rochester, NY) was used to determine the intensities of cytokine spots on each array.

\section{In Vitro Vasculogenesis Assay}

Labeled cells $\left(1 \times 10^{4}\right)$ of each population were seeded onto solidified ECMatrix (Chemicon, Temecula, Calif), with $1 \times 10^{4}$ human umbilical vein endothelial cells (HUVECs) as supporting cells. HUVECs alone were used as a control. After 24 hours of incubation, 6 random high-powered fields were taken for each cell type. The complete area of tubules formed, total tube length, and percentage contribution to the total area of capillaries were determined. 

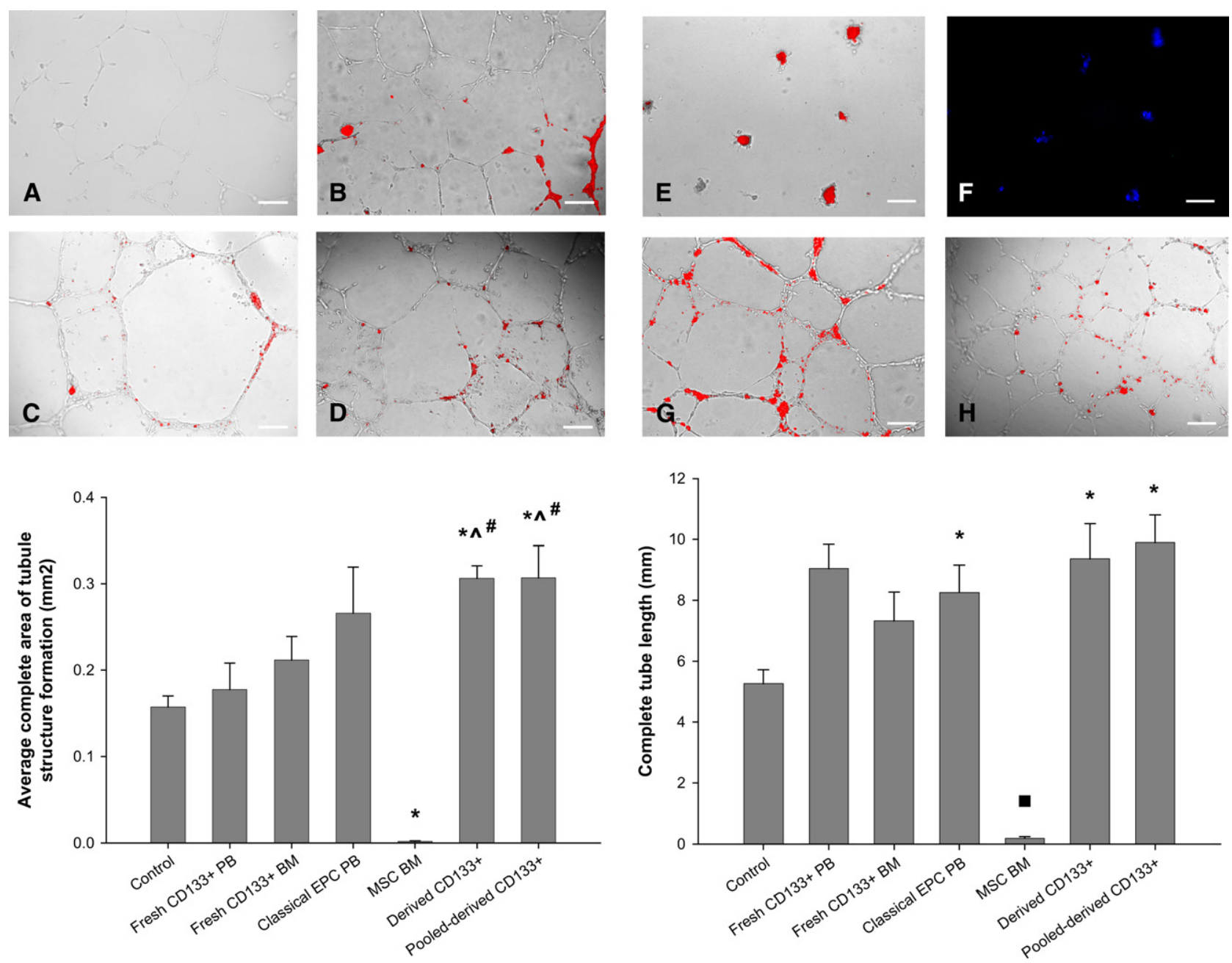

I
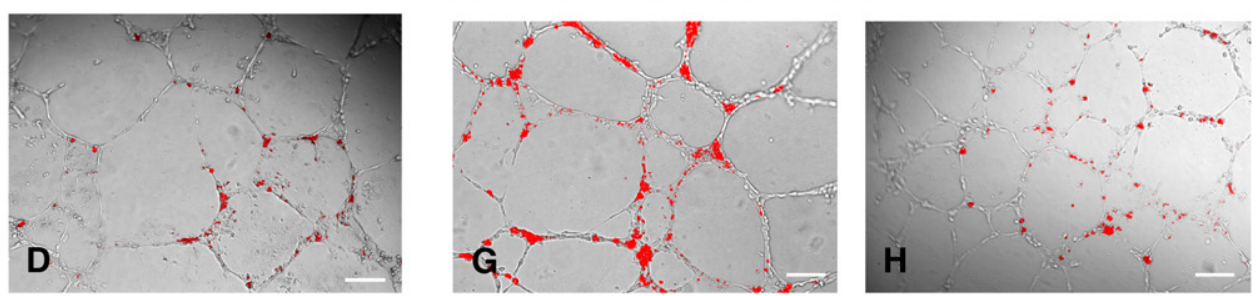

Progenitor cell populations

J

Progenitor cell populations

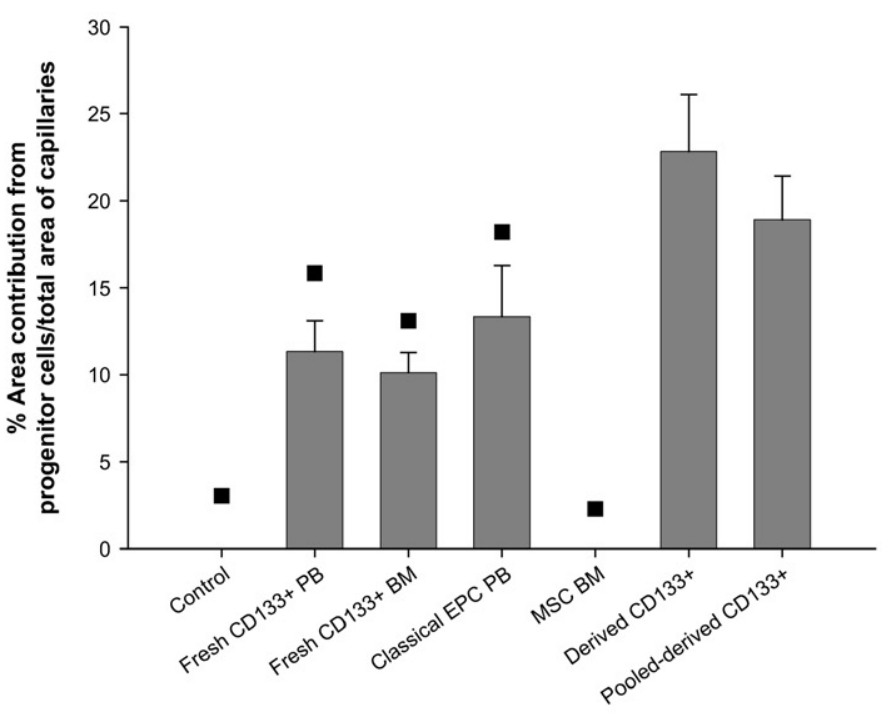

$\mathbf{K}$

Progenitor cell populations 


\section{Statistics}

Data are presented as the mean \pm standard error of the mean. Statistical analyses were performed with SigmaStat 3.1.1 (SigmaStat, Richmond, Calif). Comparisons of data between groups were performed with a 1-way analysis of variance, with Bonferroni corrections as appropriate.

\section{RESULTS}

\section{Expansion of PB CD133 ${ }^{+}$Progenitors}

The number of $\mathrm{CD} 133^{+}$cells was expanded by culturing the CD133- $\mathrm{PB}$ fraction according to 2 protocols (Figure 2, A). With protocol 1 , the culture of $\mathrm{CD} 133^{-}$cells for 14 days resulted in derived $\mathrm{CD} 133^{+}$cells $\left(0.32 \pm 0.10 \times 10^{6}\right)$, which is equivalent to a $3.09 \pm 1.37$-fold increase compared with the number of $\mathrm{CD} 133^{+}$cells in the fresh PB-MNC isolate $\left(0.12 \pm 0.03 \times 10^{6}, P<.05\right)$. With protocol 2 , after 8 days, the number of generated CD133 $3^{+}$cells in the pooledderived population $\left(1.21 \pm 0.22 \times 10^{6}\right)$ was 11 -fold greater than that obtained from the freshly isolated PB-MNCs $\left(0.14 \pm 0.03 \times 10^{6}, P<.05\right)$. Also, the number of CD133 ${ }^{+}$ cells generated in the pooled-derived group was significantly greater than that in the 14-day derived group $(P<.05)$. Expression of CD34 and VEGFR-2 on CD133 ${ }^{+}$cells obtained was examined by means of flow cytometry (see Figure E1, A). On day 0 , the proportion of circulating $\mathrm{CD} 133^{+}$cells also expressing CD34 and VEGFR-2 was $39.5 \% \pm 9.3 \%$. For days 2, 4, 6, and 8, the percentages were $67.6 \% \pm$ $9.5 \%, 56.2 \% \pm 14.5 \%, 58.0 \% \pm 8.9 \%$, and $69.4 \% \pm$ $15.1 \%$, respectively (see Figure $1, B ; P=.41$ ), suggesting that similar cell populations were being generated every 2 days.

\section{Potential Mechanisms Involved in CD133 Generation}

Fresh CD133- PB cells were cultured under 3 conditions to investigate a potential mechanism involved in the generation of $\mathrm{CD} 133^{+}$cells. The results showed that generation of $\mathrm{CD}_{133^{+}}$cells was significantly inhibited by the presence of $\mathrm{CD}_{133^{+}}$cells and by whole PB-MNC culture supernatant $\left(P<.003\right.$; Figure 2, B). When exposed to $\mathrm{CD} 133^{+}$cells, only $71.7 \% \pm 7.7 \%$ derived $\mathrm{CD} 133^{+}$cells were obtained relative to control numbers $(100 \%)$. Similarly, exposure of CD133- cells to PB-MNC supernatant resulted in only $49.4 \% \pm 9.2 \%$ generation of derived $\mathrm{CD} 133^{+}$cells compared with control numbers.

\section{Migratory Potential of Various Progenitor Cell Populations}

The VEGF-induced migration potential of 6 cell populations was tested (see Figure E2, $A-F$ ). The number of migrating cells per field of view was not significantly different between fresh $\mathrm{CD} 133^{+}$PB cells $(5.29 \pm 0.53)$ and $\mathrm{CD} 133^{+} \mathrm{BM}$ cells $(7.04 \pm 1.06)$, MSCs $(4.23 \pm 0.79)$, derived $\mathrm{CD} 133^{+} \mathrm{PB}$ cells $(3.63 \pm 0.46)$, and pooled-derived $\mathrm{CD} 133^{+} \mathrm{PB}$ cells $(5.58 \pm 0.59, P=.9)$. However, all populations had significantly lower migration compared with "classical" EPCs $(61.09 \pm 19.57)$ from PB $(P \leq .002$; Figure 3, A).

\section{Cell Interaction Effects on Migration of $\mathrm{CD}{ }^{3} 3^{+}$Cells}

Fresh and derived $\mathrm{CD}_{133^{+}}$cells were cultured with CD133- cells or their supernatant to improve CD133 ${ }^{+}$cells' migratory potential (Figure 3, $B$, and see Figure E2, $G-I$ ). When combined with CD133- cells, the number of migrating cells per field of view for both fresh $(26.87 \pm 1.52)$ and derived $(19.67 \pm 1.84) \mathrm{CD} 133^{+}$populations significantly increased when compared with the cells plated alone $(5.69 \pm 0.31$ and $3.66 \pm 0.24$, respectively; $P<.05)$. Similarly, the addition of the supernatant of CD133- cells also increased the number of migrating fresh $\mathrm{CD}_{13} 3^{+}$cells $(29.63 \pm 2.56)$. For the derived $\mathrm{CD} 133^{+}$cells, when combined with the supernatant of CD133- cells, the number of migrating cells $(30.33 \pm 1.93)$ was significantly increased compared with the number of derived $\mathrm{CD} 133^{+}$cells combined with the $\mathrm{CD} 133^{-}$cells themselves $(P<.05)$.

At the time of isolation, $59.89 \% \pm 6.41 \%$ of fresh $\mathrm{CD} 133^{+}$ cells expressed VEGFR-2, and after 24 hours of culture alone, expression decreased significantly to $48.72 \% \pm 8.37 \%$ $(P=.04)$. When the fresh $\mathrm{CD} 133^{+}$cells were cultured with CD133 cells, VEGFR-2 expression increased significantly to $74.92 \% \pm 4.36 \% \quad(P=.04)$. However, for derived CD133 $3^{+}$cells, VEGFR-2 expression before culture was $95.88 \% \pm 1.32 \%$ and did not significantly change whether cells were cultured alone $(98.18 \% \pm 0.74 \%)$ or with CD133- cells $(98.20 \% \pm 0.96 \%$, see Figure E3, $A)$.

\section{Cytokines and Growth Factors Released by CD133 Cells}

The supernatant of cultured CD133- cells was shown to have increased levels of different cytokines and growth

\footnotetext{
FIGURE 4. A-H, Representative images of the contribution of progenitor cells (red) to the formation of capillary structures with human umbilical vein endothelial cells (HUVECs): A, HUVECs alone (control); B, fresh CD133+ peripheral blood (PB) cells; C, fresh CD133 bone marrow (BM) cells; D, PB "classical" endothelial progenitor cells (EPCs); E, BM mesenchymal stem cells (MSCs); F, BM-MSCs with DAPI-stained HUVECs; G, derived CD133 PB cells; and H, pooled-derived CD133 ${ }^{+}$PB cells. Scale bar $=150 \mu \mathrm{m}$. I, Average complete area of tubule structure formation with different progenitor cell populations. Derived and pooled-derived $\mathrm{CD} 133^{+} \mathrm{PB}$ cells had significantly greater capillary formation compared with fresh $\mathrm{CD} 133^{+}$from $\mathrm{PB}(* P \leq$ $.007)$, MSCs from BM $(\wedge P<.001)$, and control HUVECs $(\# P<.05)$. J, Derived and pooled-derived CD133 $3^{+}$progenitors and fresh CD133 ${ }^{+} \mathrm{PB}$ cells had significantly greater complete tube length formation compared with control values. ${ }^{*} P<.01$ versus control; $\mathbf{\square} P<.001$ versus all cell populations. K, Derived $\mathrm{CD}_{133^{+}}$progenitors had the greatest physical contribution compared with all groups except the pooled-derived CD133 $3^{+}$cells. $\mathbf{\square} P<.001$ versus derived and pooled-derived $\mathrm{CD} 133^{+} \mathrm{PB}$ cells.
} 
factors (see Figure E3, B). These included (fold increase vs control given in parentheses) growth-related oncogene (GRO; 4.7); interleukin (IL) $1 \beta$ (2.6); IL-6 (38.0); IL-8 (23.1); IL-10 (8.9); monocyte chemoattractant protein (MCP) 1 (12.4); macrophage inflammatory protein (MIP) $1 \beta$ (3.5); regulated upon activation, normal T-cell expressed and secreted (RANTES; 3.1); and neutrophil-activating protein (NAP) 2 (3.0). The release of GRO, IL-6, IL-8, IL-10, and MCP-1 by $\mathrm{CD} 133^{-}$cells was also significantly greater than their release from cultured fresh and derived CD133 ${ }^{+}$ PB progenitor cells after 24 hours (Figure 3,C).

\section{Comparison of Vasculogenic Potential of Progenitor Populations}

In vitro vasculogenesis assays on all 6 cell populations (Figure 4, $A-H$ ) revealed that derived $\mathrm{CD} 133^{+}$cells $\left(0.31 \pm 0.02 \mathrm{~mm}^{2}\right)$ and pooled-derived $\mathrm{CD}^{2} 33^{+}$cells $\left(0.32 \pm 0.04 \mathrm{~mm}^{2}\right)$ significantly enhanced the complete area of tubules formed compared with control cells $(P<$ $.03)$, whereas MSCs $\left(0.002 \pm 0.00 \mathrm{~mm}^{2}\right)$ significantly decreased capillary formation $(P=.01$; Figure $4, I)$. Total tube length was also calculated for each cell type, revealing that derived $\mathrm{CD} 133^{+}$cells $(9.37 \pm 1.15 \mathrm{~mm})$, pooled-derived $\mathrm{CD}_{133^{+}}$cells $(9.89 \pm 0.91 \mathrm{~mm})$, and fresh $\mathrm{CD} 133^{+}$ PB cells $(9.04 \pm 0.79 \mathrm{~mm})$ had significantly enhanced capillary tube length compared with control cells $(P<.01$; Figure $4, J)$. The presence of MSCs from the BM $(0.19 \pm 0.06 \mathrm{~mm})$ created an environment that significantly inhibited the ability of HUVECs to form extended capillaries $(P<.001)$. The derived CD133 ${ }^{+}$cells $(22.84 \% \pm 3.26 \%)$ and the pooled-derived $\mathrm{CD} 133^{+}$cells $(18.90 \% \pm 2.53 \%)$ had significantly greater physical contribution to the total area of capillaries compared with the other groups $(P<$ .001 ; Figure 4, $K$ ).

\section{DISCUSSION}

Preclinical and early clinical trials have suggested that transplantation of progenitor cells has the potential to improve the function of an ischemic or infarcted myocardial territory. ${ }^{3-6,8,14,15}$ However, it still remains unknown which cell source or cell type is optimal for vascular regeneration and myocardial functional restoration. It will be crucial to elucidate the basic biology and characterization of specific populations and compare them with respect to their functional properties to optimize significant clinical benefits. In this regard the current study demonstrated the successful expansion of human $\mathrm{CD} 133^{+} \mathrm{PB}$ progenitors, which appear to be of superior vasculogenic potential for myocardial cell therapies based on in vitro comparison studies.

Previous studies showed that autologous $\mathrm{CD}_{133^{+}}$cells enhanced myocardial perfusion and global function. ${ }^{8,15,16}$ However, the frequency of $\mathrm{CD} 133^{+}$progenitors in the blood and $\mathrm{BM}$ is low, and their mechanism and function in therapeutic vasculogenesis or cell therapy remain unclear. In this study we examined $\mathrm{CD} 133^{+}$cells to better characterize these progenitors and also expanded their number for increased relevance for cell-based therapy. A nearly 11 -fold expansion of pooled-derived $\mathrm{CD} 133^{+} \mathrm{PB}$ cells was achieved by means of serial removal of the nonadherent $\mathrm{CD} 133^{+}$cells every 2 days over a period of 8 days generated from culture of the CD133- fraction of PB-MNCs. These cells also expressed CD34 and VEGFR-2 (56.2\% to $69.4 \%)$, suggesting that serial expansion generated progenitor cells similar to circulating CD133 ${ }^{+} \mathrm{CD} 34^{+}$VEGFR-2 ${ }^{+}$EPCs. $^{7}$ To a lesser extent (3-fold expansion), CD133 $3^{+} \mathrm{CD} 34^{+}$VEGFR-2 ${ }^{+}$cells were also derived from the culture of $\mathrm{CD} 133^{-}$cells after a 2week period. Our data indicate that the reduced cell expansion observed with this protocol likely resulted from the inhibitory effects of other $\mathrm{CD} 133^{+}$cells in the culture. Specifically, $\mathrm{CD} 133^{+}$cell generation was significantly inhibited by the presence of whole PB-MNC supernatant or $\mathrm{CD} 133^{+}$cells, suggesting that the removal of $\mathrm{CD} 133^{+}$ cells creates an environment conducive to $\mathrm{CD} 133^{+}$cell generation. Conversely, direct contact with $\mathrm{CD} 133^{+}$cells, the release of cytokines/soluble factors from these cells, or both might inhibit $\mathrm{CD} 133^{+}$generation through paracrine mechanisms.

Direct comparison of the derived CD133 ${ }^{+}$cells with several commonly used progenitors showed that the "classical" EPC population had the greatest migratory potential response to VEGF. "Classical" EPCs consist of a heterogeneous mix of cells, including those of monocytic, hematopoietic, and endothelial lineage, and their greater migratory potential might be related to interactions between cell populations. ${ }^{17}$ Notably, it was observed that migration was enhanced for both fresh and derived $\mathrm{CD} 133^{+} \mathrm{PB}$ progenitors when combined with $\mathrm{CD} 133^{-}$cells or their supernatant. VEGFR-2 expression on these cells was also investigated to try to explain this improved migration because VEGF was the chemotactic agent used. For fresh CD133 ${ }^{+}$ cells, VEGFR-2 expression was increased significantly when incubated with CD133- ${ }^{-}$cells. However, for derived CD133 $3^{+}$cells, the expression of VEGFR-2 (already at approximately $96 \%$ ) was not significantly changed after coculture with $\mathrm{CD} 133^{-}$cells. This can partly explain the greater improvement in migration for fresh $\mathrm{CD} 133^{+} \mathrm{PB}$ cells compared with that of derived CD133 ${ }^{+} \mathrm{PB}$ cells. Therefore one important mechanism by which interaction with CD133cells might improve migration of the $\mathrm{CD} 133^{+}$progenitor cells is increased VEGFR-2 expression.

Because $\mathrm{CD}_{133^{+}}$cell migration was significantly increased by coculture with the CD133- cell supernatant, it is likely that paracrine effects through the secretion of cytokines and chemokines are involved in regulating cell function. The $\mathrm{CD} 133^{-}$supernatant expressed increased levels of GRO, IL-1 $\beta$, IL-6, IL-8, IL-10, MCP-1, MIP $1 \beta$, RANTES, and NAP- 2 compared with control values. Therefore provision of cytokines and growth factors from other 
circulating cell populations might be involved in regulating the migratory capacity of $\mathrm{CD} 133^{+}$progenitor cells. In addition, recent evidence suggests that neovascularization/vasculogenesis of the dysfunctional myocardium from paracrine and humoral factors and secondary recruitment of host cells are the likely mechanisms leading to functional improvement in patients with CAD. ${ }^{19,20}$

This study also revealed that derived $\mathrm{CD} 133^{+}$cells are functionally more potent than several other select progenitor cells with respect to their vasculogenic potential in vitro. Overall, the derived $\mathrm{CD} 133^{+}$cells demonstrated significantly greater contribution to forming capillary-like structures in vitro (incorporation, total capillary area, and length). The capacity of freshly isolated $\mathrm{CD} 133^{+} \mathrm{CD} 34^{+}$VEGFR-2 $2^{+}$cells to yield endothelial cells has recently been questioned. ${ }^{18}$ However, the greater direct incorporation of derived $\mathrm{CD}_{133^{+}}$progenitor cells into capillary-like structures observed in this study suggests that these cells might have improved endothelial differentiation. It is possible that intercellular interaction between different cell types is required for optimal function of the CD133 ${ }^{+} \mathrm{CD} 34^{+}$VEGFR-2 $2^{+}$population, a consideration not explored in the previous study. Alternatively, greater paracrine effects of derived $\mathrm{CD} 133^{+}$cells on the HUVECs is suggested by the greater total capillary area and length seen with the addition of derived CD133 ${ }^{+}$ cells compared with the other progenitor populations.

Interestingly, the 2 cell populations from the BM differed in their in vitro vasculogenic potential: the fresh $\mathrm{CD} 133^{+}$ fraction contributed to capillary-like formation, whereas the cultured MSCs did not. Although these are in vitro results, this is consistent with recent evidence demonstrating that different cell populations from the BM differ in their vasculogenic potential. ${ }^{21}$ Also, it has been demonstrated that without prior environmental conditioning or differentiation into endothelial cells, the ability of MSCs to contribute to capillary-like structures in Matrigel is compromised. ${ }^{22}$ It was shown that the ability of the BM population to contribute in vasculogenesis was associated with the positive expression of the endothelial cell-surface markers CD34, VEGFR-2, and/or CD $31 .^{22}$

However, the limitations of this study need to be acknowledged. First, all functional evaluations and comparisons were performed in in vitro assays. Nevertheless, previous studies have reported that similar results were obtained in in vitro migration and vasculogenesis assays versus in vivo studies. ${ }^{23,24}$

Second, in this study only VEGF-induced migration capability was assessed. Several chemokines and growth factors have been shown to be responsible for stem cell homing and migration to the myocardium, such as VEGF, stromal cellderived factor 1, MCP-3, hepatocyte growth factor, fibroblast growth factor 2 , and insulin-like growth factor 1 . These different factors recruit and regulate different stem cell populations. VEGF is a potent and highly specific mitogen for EPCs, and previous data indicate that VEGF overexpression improves EPC migratory, adhesive, and proliferative capabilities both in vitro and in vivo. ${ }^{25}$

To our knowledge, this is the first study to directly compare the functional properties of 5 commonly used progenitor cell populations in simple in vitro experiments in an effort to elucidate the vasculogenic potential of these cells. Derived $\mathrm{CD} 133^{+}$cells appear to be a superior source of vasculogenic cells for transplantation based on this study. Also, interactions (cytokine/paracrine mechanism) between cell populations in vitro were observed to improve the migratory function of $\mathrm{CD}_{13} 3^{+}$progenitor cells, which might have implications for clinical applications as well. Therefore derived $\mathrm{CD} 133^{+} \mathrm{PB}$ cells merit further investigation as potentially more effective and potent endothelial progenitors for cardiac cell-based therapy. Interactions between cell populations also require further attention to improve current cell-based vasculogenic therapies. An optimal cell population for cell-based vasculogenic treatment might exist that is likely a combination of different subtypes that can augment/participate in vasculogenesis, that require interaction with the host cells for maximal therapeutic effect, or both.

In conclusion, despite heightened expectations, the benefits of cell-based cardiac therapy have not yet been established in patients. The field must remain willing to return to the laboratory to improve our mechanistic understanding and refine our therapeutic approaches. The present study, albeit in vitro, attempted to perform this by comparing different cell populations for the first time, by investigating cell-cell and cell-soluble factor interactions, and by testing a method to expand a rare progenitor identified as being more vasculogenically potent than other commonly used cell populations.

\section{References}

1. Ruel M, Song J, Sellke FW. Protein-, gene-, and cell-based therapeutic vasculogenesis for the treatment of myocardial ischemia. Mol Cell Biochem. 2004;264: 119-31.

2. Gnecchi M, Zhang Z, Ni A, Dzau VJ. Paracrine mechanisms in adult stem cell signaling and therapy. Circ Res. 2008;103:1204-19.

3. Suuronen EJ, Price J, Veinot JP, Ascah K, Kapila V, Guo XW, et al. Comparative effects of mesenchymal progenitor cells, endothelial progenitor cells, or their combination on myocardial infarct regeneration and cardiac function. $J$ Thorac Cardiovasc Surg. 2007;134:1249-58.

4. Stamm C, Westphal B, Kleine HD, Petzsch M, Kittner C, Klinge H, et al. Autologous bone-marrow stem-cell transplantation for myocardial regeneration. Lancet. 2003;361:45-6.

5. Hofmann M, Wollert KC, Meyer GP, Menke A, Arseniev L, Hertenstein B, et al. Monitoring of bone marrow cell homing into the infarcted human myocardium. Circulation. 2005;11:2198-202.

6. Zhang Y, Thorn S, DaSilva JN, Lamoureux M, deKemp RA, Beanlands RS, et al. Collagen-based matrices improve the delivery of transplanted circulating progenitor cells: development and demonstration by ex vivo radionuclide cell labeling and in vivo tracking with positron emission tomography. Circ Cardiovasc Imag ing. 2008;1:197-204.

7. Peichev M, Naiyer AJ, Pereira D, Zhu Z, Lane WJ, Williams M, et al. Expression of VEGFR-2 and AC133 by circulating human CD34(+) cells identifies a population of functional endothelial precursors. Blood. 2000;95:952-8. 
8. Stamm C, Kleine HD, Choi YH, Dunkelmann S, Lauffs JA, Lorenzen B, et al. Intramyocardial delivery of CD133+bone marrow cells and coronary artery bypass grafting for chronic ischemic heart disease: safety and efficacy studies. $J$ Thorac Cardiovasc Surg. 2007;133:717-25.

9. Masuda H, Asahara T. Post-natal endothelial progenitor cells for neovascularization in tissue regeneration. Cardiovasc Res. 2003;58:390-8.

10. Powell TM, Paul JD, Hill JM, Thompson M, Benjamin M, Rodrigo M, et al. Granulocyte colony-stimulating factor mobilizes functional endothelial progenitor cells in patients with coronary artery disease. Arterioscler Thromb Vasc Biol. 2005;25:296-301.

11. Hill JM, Syed MA, Arai AE, Powell TM, Paul JD, Zalos G, et al. Outcomes and risks of granulocyte colony-stimulating factor in patients with coronary artery disease. J Am Coll Cardiol. 2005;46:1643-8.

12. Suuronen EJ, Wong S, Kapila V, Waghray G, Whitman SC, Mesana TG, et al. Generation of CD133(+) cells from CD133(-) peripheral blood mononuclear cells and their properties. Cardiovasc Res. 2006;70:126-35.

13. Ruel M, Suuronen EJ, Song J, Kapila V, Gunning D, Waghray G, et al. Effects of offpump versus on-pump coronary artery bypass grafting on function and viability of circulating endothelial progenitor cells. J Thorac Cardiovasc Surg. 2005;130:633-9.

14. Assmus B, Schachinger V, Teupe C, Britten M, Lehmann R, Dobert N, et al. Transplantation of progenitor cells and regeneration enhancement in acute myocardial infarction (TOPCARE-AMI). Circulation. 2002;106:3009-17.

15. Bartunek J, Vanderheyden M, Vandekerckhove B, Mansour S, De Bruyne B, De Bondt $\mathrm{P}$, et al. Intracoronary injection of CD133-positive enriched bone marrow progenitor cells promotes cardiac recovery after recent myocardial infarction: feasibility and safety. Circulation. 2005;112(suppl):I178-83.

16. Suuronen EJ, Veinot JP, Wong S, Kapila V, Price J, Griffith M, et al. Tissue-engineered injectable collagen-based matrices for improved cell delivery and vascularization of ischemic tissue using CD133+ progenitors expanded from the peripheral blood. Circulation. 2006;114(suppl):I138-44.
17. Shantsila E, Watson T, Lip GY. Endothelial progenitor cells in cardiovascular disorders. J Am Coll Cardiol. 2007;49:741-52.

18. Case J, Mead LE, Bessler WK, Prater D, White HA, Saadatzadeh MR, et al. Human CD34 + AC133 + VEGFR-2+ cells are not endothelial progenitor cells but distinct, primitive hematopoietic progenitors. Exp Hematol. 2007;35: 1109-18.

19. Yoon CH, Hur J, Park KW, Kim JH, Lee CS, Oh IY, et al. Synergistic neovascularization by mixed transplantation of early endothelial progenitor cells and late outgrowth endothelial cells: the role of vasculogenic cytokines and matrix metalloproteinases. Circulation. 2005;112:1618-27.

20. Ruel M, Laham RJ, Parker JA, Post MJ, Ware JA, Simons M, et al. Long-term effects of surgical angiogenic therapy with fibroblast growth factor 2 protein. J Thorac Cardiovasc Surg. 2002;124:28-34.

21. Copland I, Sharma K, Lejeune L, Eliopoulos N, Stewart D, Liu P, et al. CD34 expression on murine marrow-derived mesenchymal stromal cells: impact on neovascularization. Exp Hematol. 2008;36:93-103.

22. Annabi B, Lee YT, Turcotte S, Naud E, Desrosiers RR, Champagne M, et al. Hypoxia promotes murine bone-marrow-derived stromal cell migration and tube formation. Stem Cells. 2003;21:337-47.

23. Heeschen C, Lehmann R, Honold J, Assmus B, Aicher A, Walter DH, et al. Profoundly reduced neovascularization capacity of bone marrow mononuclear cells derived from patients with chronic ischemic heart disease. Circulation. 2004;109:1615-22.

24. Matsuura K, Honda A, Nagai T, Fukushima N, Iwanaga K, Tokunaga M, et al. Transplantation of cardiac progenitor cells ameliorates cardiac dysfunction after myocardial infarction in mice. J Clin Invest. 2009;119: 2204-17.

25. Iwaguro H, Yamaguchi J, Kalka C, Murasawa S, Masuda H, Hayashi S, et al. Endothelial progenitor cell vascular endothelial growth factor gene transfer for vascular regeneration. Circulation. 2002;105:732-8. 


\section{MATERIALS AND METHODS}

\section{Isolation of $\mathrm{CD} 133^{+}$Cells From PB}

Total PB-MNCs were freshly isolated from the blood of human donors by using Histopaque1077 (Sigma) densitygradient centrifugation of buffy coats. On the initial day of PB-MNC isolation, CD133+ cells were separated from PB-MNCs by using CD133- microbeads and a magnetically activated cell sorter (autoMACS; Miltenyi Biotech, Bergisch-Gladbach, Germany), thereby providing day 0 (fresh) $\mathrm{CD}_{133^{+}}$cells and CD133- $\mathrm{PB}$ cells.

\section{Expansion of CD133 ${ }^{+}$Cells From CD133 ${ }^{-}$PB Fractions}

CD133- fractions were plated on fibronectin-coated, 12-well culture plates (Becton Dickinson, Mississauga, Canada) at a density of $1 \times 10^{6}$ cells $/ \mathrm{cm}^{2}$ in EBM-2 supplemented with EGM-2-MV-SingleQuots (Clonetics) containing $5 \%$ fetal bovine serum, $50 \mathrm{ng} / \mathrm{mL}$ human VEGF, $50 \mathrm{ng} / \mathrm{mL}$ human insulin-like growth factor 1 , and $50 \mathrm{ng} / \mathrm{mL}$ human epidermal growth factor. Two different protocols were used to obtain derived $\mathrm{CD} 133^{+} \mathrm{PB}$ cells. Cells in protocol 1 had fresh media added to the wells every 3 days without aspiration of the old media. After 14 days, both adherent and nonadherent cells were collected and separated by means of autoMACS to obtain derived $\mathrm{CD} 133^{+} \mathrm{PB}$ cells. In protocol 2 the nonadherent population was removed every 2 days over a period of 8 days and separated with the autoMACS machine to collect $\mathrm{CD} 133^{+}$cells. The generated $\mathrm{CD} 133^{+}$cells were cryopreserved in $1-\mathrm{mL}$ aliquots with $10 \%$ dimethyl sulfoxide in complete media. After 8 days, cryopreserved cells from days $0,2,4,6$ and 8 were thawed and combined to constitute the pooled-derived $\mathrm{CD} 133^{+}$population (hereafter referred to as pooled-derived CD133 ${ }^{+}$PB cells).

\section{Isolation of EPCs}

Briefly, total human PB-MNCs were cultured in supplemented EBM-2 media on fibronectin-coated tissue-culture plates $\left(1 \times 10^{6} \mathrm{MNCs} / \mathrm{cm}^{2}\right)$ for 4 days. The adherent cells, hereafter referred to as "classical" EPCs, were then collected.

\section{Isolation of $\mathrm{CD133}^{+}$Cells and MSCs From BM}

Donor marrow was aspirated from the sternum with a standard marrow aspiration needle and washed in Hanks balanced salt solution (Gibco Invitrogen, Burlington, Canada) to obtain BM cells. Bone marrow was digested completely with collagenase type I ( $250 \mathrm{U} / \mathrm{mL}$, Gibco Invitrogen), and the cell suspension was filtered with a 70- $\mu$ m nylon cell strainer (Becton Dickinson). Isolated BM-MNCs were separated from the $\mathrm{CD} 133^{-}$fraction by means of autoMACS to obtain day 0 (fresh) $\mathrm{CD} 133^{+} \mathrm{BM}$ cells. The filtered cell suspension was washed and plated at $1.3 \times 10^{6}$ cells $/ \mathrm{cm}^{2}$ in Dulbecco's modified Eagle's medium supplemented with $10 \%$ fetal bovine serum (Gibco Invitrogen), $2 \mathrm{mmol} /$ L L-glutamine (Sigma), and $100 \mathrm{U} / \mathrm{mL}$ penicillin/streptomycin (Gibco Invitrogen) to obtain ex vivo expanded MSCs. After 4 days, the nonadherent cells were removed. The media was replaced every 3 days for 2 weeks or until the adherent MSC population was $80 \%$ to $90 \%$ confluent. The phenotype of the MSC population was characteristically $\mathrm{CD} 29^{+} \mathrm{CD} 44^{+} \mathrm{CD} 45^{-}$(data not shown). 

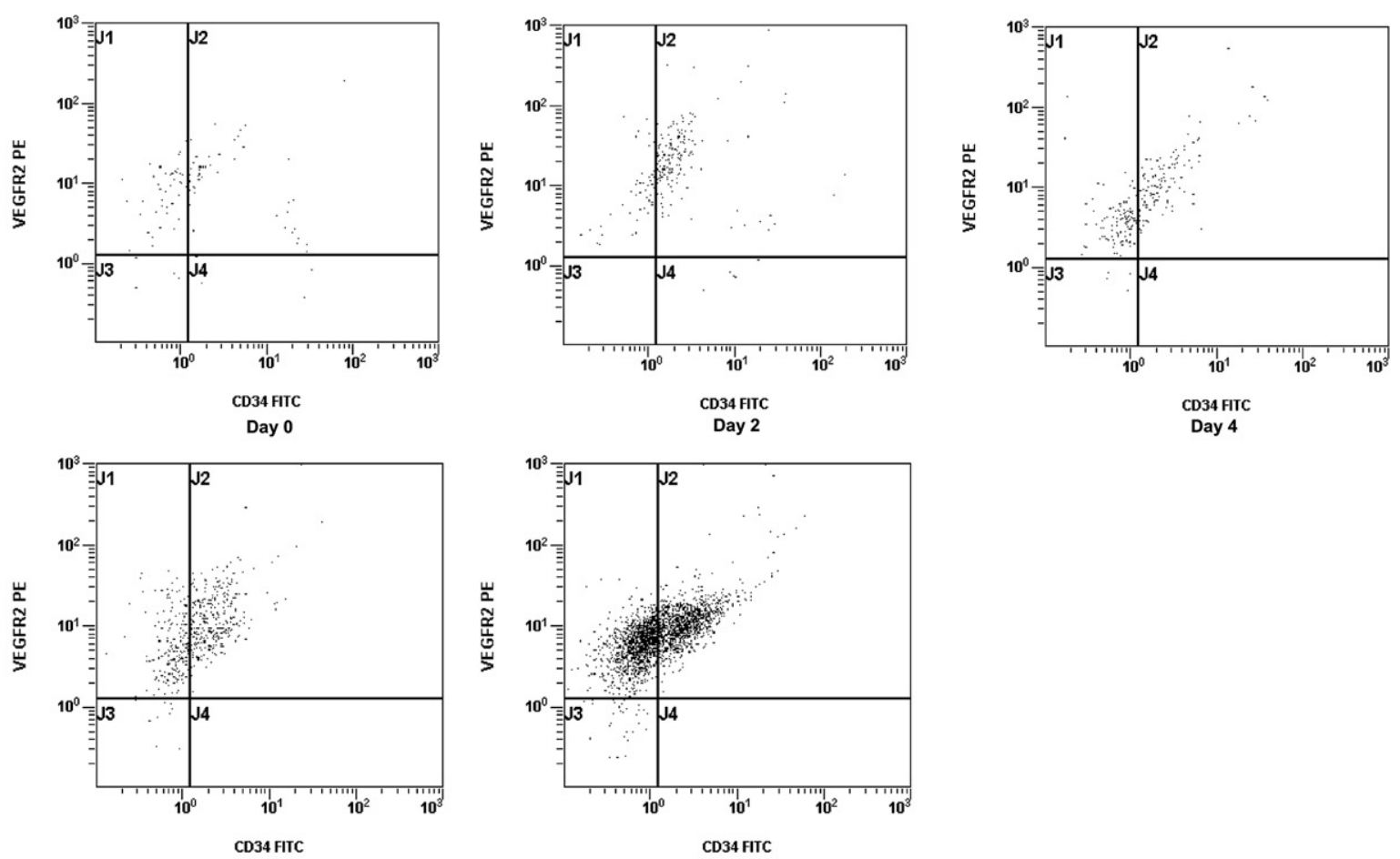

A

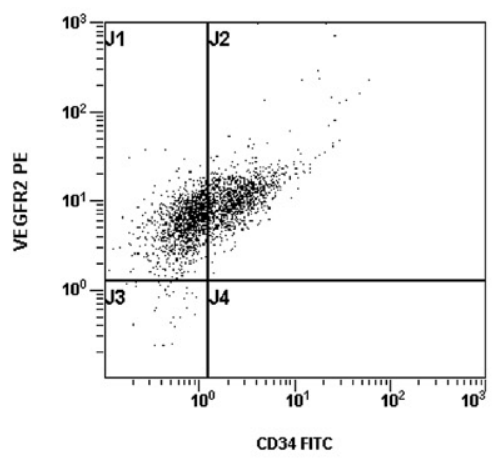

Day 8
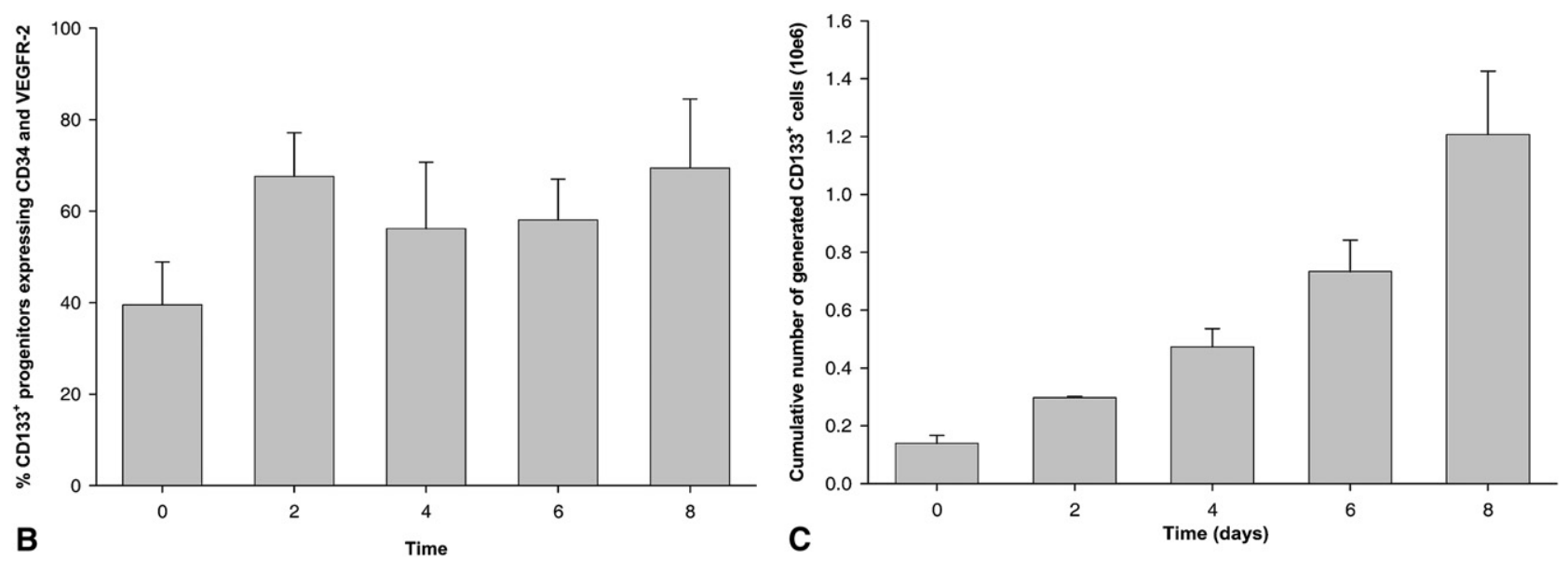

FIGURE E1. Cell expansion. A, Representative flow cytometric analysis for coexpression of CD34 and vascular endothelial growth factor receptor 2 (VEGFR-2) on fresh and serially derived $\mathrm{CD} 133^{+}$cells collected every 2 days for a period of 8 days. PE, Phycoerythrin; FITC, fluorescein isothiocyanate. $\mathrm{B}$, Flow cytometric results showing the percentage of CD133 ${ }^{+}$cells also expressing CD34 and VEGFR-2 over 8 days. C, Cumulative number of generated $\mathrm{CD} 133^{+}$cells removed every 2 days from the serial culture of the $\mathrm{CD} 133^{-}$fraction of peripheral blood mononuclear cells. $* P<.001$ for day 8 versus other times. 

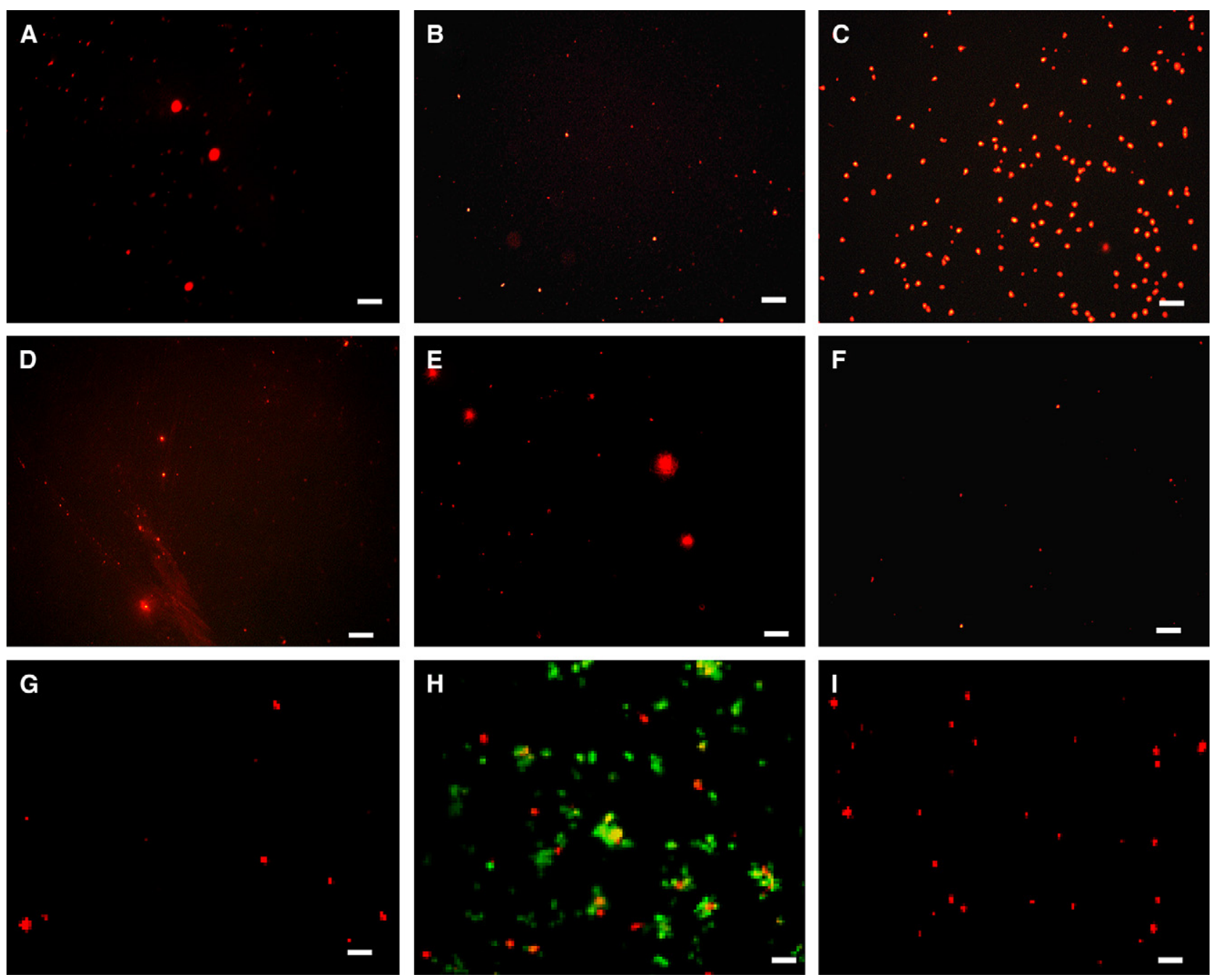

FIGURE E2. Cell migration. A-F, The migration properties of 6 cell populations. Representative migration assay images of fresh CD133 $3^{+}$peripheral blood (PB) cells (A), fresh CD133+ bone marrow (BM) cells (B), PB “classical”' endothelial progenitor cells (C), BM mesenchymal stem cells (D), derived CD133 PB cells (E), and pooled-derived CD133 $3^{+}$PB cells (F) are shown. G-I, Cell interaction effects on CD133 ${ }^{+}$cell migration. Representative migration assay images of derived $\mathrm{CD} 133^{+}$cells alone (G), derived CD133+ cells with $\mathrm{CD} 133^{-}$cells $(\mathrm{H})$, and derived $\mathrm{CD} 133^{+}$cells with $\mathrm{CD} 133^{-}$cell supernatant $(\mathrm{I})$ after 24 hours of culture are shown. Scale bar $=75 \mu \mathrm{m}$. 


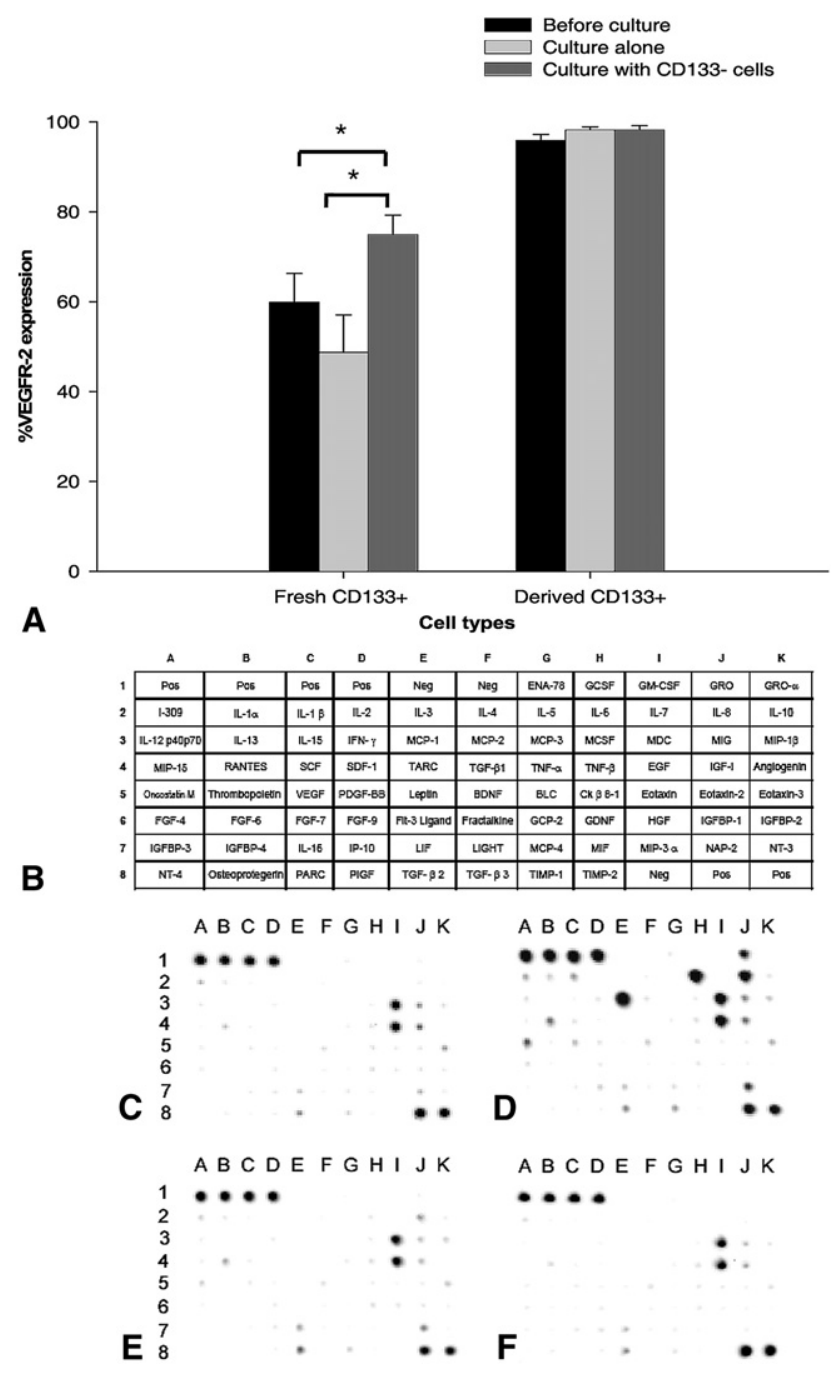

FIGURE E3. Mechanisms involved in the migration improvement by cell interactions. A, Expression of vascular endothelial growth factor receptor 2 (VEGFR-2) on fresh or derived $\mathrm{CD} 133^{+}$cells cultured with or without CD133- cells for 24 hours. $* P<.05$. B-F, Representative cytokine/growth factor array images of cytokine/growth factor map of array membrane (B), culture medium only $(\mathrm{C}), \mathrm{CD}_{133^{-}}$peripheral blood $(\mathrm{PB})$ cell supernatant after 24 hours of incubation (D), fresh $\mathrm{CD} 133^{+} \mathrm{PB}$ cell supernatant after 24 hours of incubation (E), and derived $\mathrm{CD} 133^{+} \mathrm{PB}$ cell supernatant $(\mathrm{F})$ after 24 hours of incubation are shown. Pos, Positive; Neg, negative; ENA-78, epithelial cell-derived neutrophil-activating protein-78; $G C S F$, granulocyte colony-stimulating factor; $G M-C S F$, granulocyte-macrophage colonystimulating factor; $G R O$, growth-related oncogene; $I-309$, a small glycoprotein secreted by activated T-cells; $I L$, interleukin; $I F N$, interferon; $M C P$, monocyte chemoattractant protein; $M C S F$, macrophage colony-stimulating factor; $M D C$, macrophage-derived chemokine; $M I G$, monokine induced by gamma interferon; $M I P$, macrophage inflammatory protein; RANTES, regulated upon activation normal T cell expressed and secreted; $S C F$, stem cell factor; $S D F$, stromal cell-derived factor; TARC, thymus and activation-regulated chemokine; $T G F$, transforming growth factor; TNF, tumor necrosis factor; $E G F$, epidermal growth factor; $I G F$, insulin-like growth factor; $V E G F$, vascular endothelial growth factor; $P D G F$, platelet-derived growth factor; $B D N F$, brain-derived neurotrophic factor; $B L C$, B-lymphocyte chemoattractant; $F G F$, fibroblast growth factor; $G C P$, granulocyte chemotactic protein; $G D N F$, glial cell line-derived neurotrophic factor; $H G F$, hepatocyte growth factor; $I G F B P$, insulin-like growth factor-binding protein; $I P-10$, interferon-inducible protein $10 ; L I F$, leukemia inhibitory factor; $L I G H T$, lymphotoxin-related inducible ligand that competes for glycoprotein $\mathrm{D}$ binding to herpes virus entry mediator on T-cells; $M I F$, macrophage migration inhibitory factor; $N A P$, neutrophil-activating protein; $N T$, neurotrophic factor; $P A R C$, pulmonary and activation-regulated chemokine; $P I G F$, placental growth factor; TIMP, tissue inhibitor of metalloproteinases. 